\title{
Convenção das Nações Unidas sobre os Direitos da Criança / The United Nations Convention on the Rights of the Child
}

https://doi.org/10.21814/uminho.ed.36.12

\section{Matías Cordero Arce}

Independent Researcher and Educator at a Young Offenders' Institution in the Basque Country, Spain 



\section{Convenção das Nações Unidas Sobre os Direitos da Criança}

A Convenção das Nações Unidas sobre os Direitos da Criança (CDC), adotada pela Assembleia Geral da ONU em 1989, é um dos principais instrumentos internacionais de direitos humanos. Complementada por três protocolos opcionais - sobre a venda de crianças, crianças em conflito armado e sobre procedimentos de comunicação - estabelece um Comité formado por especialistas que monitorizam a implementação das suas disposições e dos seus protocolos opcionais pelos Estados Partes. Até ao momento, é o tratado internacional de direitos humanos mais amplamente ratificado da história.

Uma característica distinta da CDC, que a diferencia de outros instrumentos fundamentais de direitos humanos, é que os direitos que ela consagra não são o resultado das lutas dos seus destinatários pelos seus direitos, mas sim de adultos que decidiram que as crianças necessitavam de uma Convenção, elaborando, assim, uma para elas. Esta Convenção, redigida por adultos, é ela própria implementada em contextos sociais que, em todo o mundo, podem, ainda, ser descritos como preeminentemente adultista, como os Estudos da Infância têm documentado exaustivamente.

A CDC e a tendência adulta que a atravessa podem ser mais bem compreendidas se nos concentrarmos nos seus quatro princípios orientadores, identificados pelo seu Comité e agora universalmente aceites como a espinha dorsal e a estrutura interpretativa da CDC pelos Estados Partes, ONG, académicos e profissionais.

Em primeiro lugar, o princípio do direito à participação, contido pelo Comité no artigo $12 .^{\circ}$, que obriga os Estados Partes a "assegurar à criança... capaz de formar as suas próprias opiniões o direito de expressar essas opiniões livremente em todos assuntos que a afetam", essas visões "tendo o devido peso de acordo com a idade e maturidade da criança”. No entanto, como implícito na elaboração e confirmado pela prática, o peso atribuído aos seus pontos de vista e a correlação da sua "idade e maturidade" com tudo isso vai depender, em última análise, da avaliação do supervisor adulto.

É indicativo do adultismo generalizado que moldou esta conceção do papel supervisionado e subordinado das crianças na sociedade que, como mostra a história da CDC, os delegados adultos que elaboraram a CDC não 
pensaram que a própria Convenção era algo em que as crianças deveriam ter tido uma palavra a dizer. Assim, as crianças não foram autorizadas a participar na elaboração da carta dos seus próprios direitos e têm, também, uma palavra marginal a respeito da sua implementação.

Em segundo lugar, o artigo $6 .^{\circ}$ consagra o princípio do direito das crianças à vida, sobrevivência e desenvolvimento. Resumir este artigo como um princípio-chave mostra a influência do desenvolvimentismo na elaboração e implementação da CDC. As crianças devem ser protegidas e sustentadas ("vida e sobrevivência") à medida que as suas capacidades "evoluem" (artigos $5 .^{\circ}$ e $14 .^{\circ}$ ); à medida que "crescem e amadurecem" (artigo 12..$^{\circ}$ ), isto é, à medida que se desenvolvem em direção ao seu estado final humano ideal, que é a idade adulta. Na verdade, a participação das crianças, nos termos do artigo $12 .^{\circ}$, é supervisionada e protegida justamente porque as crianças ainda não atingiram a idade adulta, um estado final que thes conferiria a racionalidade e consequente independência e competência que ainda não possuem. Por causa dessa consideração de dependência e incompetência, as crianças também são consideradas ainda irresponsáveis: a educação, que é equiparada à escolaridade pela CDC (artigo $28 .^{\circ}$ ), deve ter como objetivo "a preparação da criança para uma vida responsável numa sociedade livre" (artigo $29 .^{\circ}$, n. $^{\circ} 1$ d). Assim, as crianças, para a CDC, não têm obrigações e estão ainda a tornar-se responsáveis, portanto, são cidadãos apenas em formação.

Terceiro, 0 artigo $3 .^{\circ}$ diz que "em todas as ações relativas às crianças... o superior interesse da criança deve ser uma consideração primária”. Este princípio do interesse superior é anterior à CDC e surgiu como um critério paternalista devido às conceções desenvolvimentistas, e não como um direito das crianças. $O$ seu objetivo era orientar os adultos que tomam decisões sobre as crianças e foi por isso que foi incluído na CDC. Além disso, como critério, é totalmente aberto, o que significa que a sua aplicação dependerá inteiramente do sistema de valores do decisor adulto.

Quarto, o artigo 2. ${ }^{\circ}$ consagra o princípio do chamado direito à não discriminação, seja em razão de "raça, cor, sexo, idioma, religião, opinião política ou outra, origem nacional, étnica ou social, propriedade, deficiência, nascimento ou outro estatuto". Este é um princípio importante na medida em que defende a igualdade de direitos de meninas e "crianças negras", "cegas", "gays", "pobres", "imigrantes", etc. Porém, nem a CDC, nem o seu Comité ou intérpretes consideram a idade uma variável de estatuto social. Assim, a CDC não reconhece a possibilidade de ser discriminado simplesmente por ser criança, o que é revelador da sua origem, interpretação e aplicação adultocêntrica. A CDC procura 
defender as crianças contra o sexismo, racismo, homofobia, classismo e outras estruturas de opressão, mas não estende essa defesa ao adultismo, que é precisamente a forma de opressão estrutural sofrida pelas crianças enquanto crianças. Um exemplo claro disso é a discriminação enfrentada por crianças trabalhadoras em todo o mundo (ver "trabalho infantil" e "protagonismo").

Considerando a breve descrição dos três princípios anteriores, a lacuna oximorónica de excluir a idade como uma variável de estatuto social no quarto princípio não deveria surpreender, porque a CDC revela-se como uma peça de legislação adultocêntrica, geralmente implementada num contexto social adulto. Tal expõe outra anomalia da CDC vis-à-vis com os outros instrumentos fundamentais de direitos humanos que podem ser vistos, por exemplo, se considerarmos a Convenção para a Eliminação de Todas as Formas de Discriminação contra Mulheres (CEDM), e a Convenção sobre a Eliminação de Todas as Formas de Discriminação Racial (CERD). No caso destas duas Convenções, pode-se dizer que a CEDM foi elaborada justamente para lutar e eliminar o sexismo, e que a CERD foi elaborada para combater e eliminar o racismo. Porém, no caso da CDC, não se pode dizer que surgiu para lutar e eliminar o adultismo.

Em suma, a CDC tem uma marca adultista que tende a reduzir os direitos das crianças às obrigações dos adultos para com elas, nomeadamente a obrigação de as cuidar e proteger (incluindo uma participação protegida). Enquanto convenção adultista, tem ajudado na proteção das crianças em todo o mundo, ao permear os sistemas jurídicos nacionais, aumentando a consciência global da importância dos direitos da criança assim compreendidos, estabelecendo novos padrões para avaliar o cumprimento da legislação dos direitos da criança, ou promovendo o surgimento de provedores para proteger os direitos das crianças em vários países.

Por causa disso, mas principalmente por causa da posição hegemónica da CDC - é a única carta global dos direitos da criança existente, sem que haja qualquer movimento internacional de base infantil que pressione por outra carta - ela deve ser reconhecida como a moeda legal em uso em relação aos direitos da criança.

No entanto, uma advertência fundamental deve ser feita sublinhando que como instrumento dos direitos das crianças, isto é, dos direitos que deveriam pertencer às crianças, a CDC é uma ferramenta "à espera"; à espera que as crianças venham e criem um espaço para os seus próprios significados e definições num espaço originalmente não criado por elas. As crianças trabalhadoras organizadas no mundo maioritário já começaram a trilhar 
esse caminho, utilizando o discurso sobre os seus direitos consagrados na CDC para lutar por mais direitos, como o direito de trabalhar com dignidade que não está incluído na CDC.

\section{The United Nations Convention on The Rights of The Child}

The United Nations Convention on the Rights of the Child (UNCRC), adopted by the UN General Assembly in 1989, is one of the core international human rights instruments. Supplemented by three optional protocols - on the sale of children, children in armed conflict, and a communications procedure - it establishes a Committee formed by experts who monitor the implementation of its provisions and its optional protocols by its States parties. To date, it is the most widely ratified international human rights treaty in history.

A distinct feature of the UNCRC that differentiates it from other core human rights instruments, is that the rights it enshrines are not the result of the struggles for the rights of its addressees, but of adults deciding for children that these needed a Convention, and thus writing it down for them. This adult-drafted Convention is itself implemented in social contexts that, worldwide, can still be described as pre-eminently adultist, as Childhood Studies have thoroughly documented.

The UNCRC and the adultist bias that runs right through it can be best understood if we focus on its four guiding principles, identified by its Committee and now universally accepted as the backbone and interpretative framework of the UNCRC by States parties, NGOs, scholars and practitioners.

Firstly, there is the principle of the right to participation, encapsulated by the Committee and interpreters of the UNCRC in article 12, which mandates States Parties to "assure the child... capable of forming his or her own views, the right to express those views freely in all matters affecting the child", these views "being given due weight in accordance with the age and maturity of the child". However, as implied by the drafting and confirmed by practice, whether the child is capable of forming his or her views, which matters affect the child, the weight ascribed to the child's views, and the correlation of the child's "age and maturity" with all the above, will ultimately depend on the evaluation of the adult supervisor. It is indicative of the pervasive adultism that shaped this conception of children's supervised and subordinated role in society that, as the history of the UNCRC shows, the adult delegates that drafted the UNCRC did not think that the Convention was itself something about which children had to have a say. Thus, children 
were not allowed to participate in the drafting of their own charter of rights, and still have very little say regarding its implementation.

Secondly, article 6 enshrines the principle of children's right to life, survival, and development. Enshrining this article as a key principle shows the influence of developmentalism in the drafting and implementation of the UNCRC. Children have to be protected and provided for ("life and survival") as their capacities "evolve" (articles 5 and 14); as they "age and mature" (article 12), that is, as they develop towards their ideal human end-state, which is adulthood. Actually, children's participation, as per article 12, is supervised and protected precisely because children have still not achieved adulthood, an end-state that would grant them the rationality and subsequent independence and competence that they do not have yet. Because of this consideration of dependency and incompetence, children are also considered to be still irresponsible: education, which is equated to schooling by the UNCRC (article 28), has to aim for "the preparation of the child for responsible life in a free society" (article 29 n.1 d). So, children, for the UNCRC, are dutyless and becoming responsible, and therefore, just citizens in-the-making.

Thirdly, article 3 says that "in all actions concerning children... the best interests of the child shall be a primary consideration". This principle of the best interests predates the UNCRC and emerged as a paternalist criterion indebted to developmentalist conceptions, rather than as a right of children. Its purpose was to guide the adults who make decisions about children and it was as such that it was included in the UNCRC. Further, as a criterion it is utterly open-ended, which means that its application will depend entirely upon the value-system of the adult decision-maker.

Fourthly, article 2 enshrines the principle of the so-called right to non-discrimination, be it because of "race, colour, sex, language, religion, political or other opinion, national, ethnic or social origin, property, disability, birth or other status". This is an important principle since it defends the equal rights of girls, and children who are black, blind, gay, poor, immigrant, etc. However, neither the UNCRC, nor its Committee or interpreters, consider age as a variable of social status. Thus, the UNCRC does not acknowledge the possibility of being discriminated against simply because of being a child, which reveals its adultist origin, interpretation and implementation. The UNCRC seeks to defend children against sexism, racism, homophobia, classism and other structures of oppression, but it does not extend that defense to the case of adultism, which is precisely the form of structural oppression suffered by children as children. A clear example of this is the discrimination faced by working children worldwide (see "child labour" and "protagonism"). 
Considering the brief depiction of the prior three principles, the oxymoronic lacuna of excluding age as a variable of social status in the fourth should come as no surprise, because UNCRC reveals itself as an adultist piece of legislation, generally implemented in an adultist social context. This exposes another anomaly of the UNCRC vis-à-vis the other core human rights instruments, that can be seen if, for example, we consider the CEDAW (Convention on the Elimination of All Forms of Discrimination against Women), and the CERD (Convention on the Elimination of All Forms of Racial Discrimination). In the case of these two Conventions, it can reasonably be said that the CEDAW was drafted precisely to fight and eliminate sexism, and that the CERD was drafted to fight and eliminate racism. However, in the case of the UNCRC, it cannot reasonably be said that it emerged to fight and eliminate adultism.

In sum, the UNCRC has an adultist imprint which tends to reduce children's rights to adult obligations towards children, namely the obligation to provide for children and to protect them (including a protected participation). As such an adultist Convention, it has been helpful for the protection of children throughout the world, by permeating national legal systems, raising global awareness of the importance of children's rights thus understood, setting new standards to evaluate the compliance with children's rights law, or promoting the emergence of ombudspersons to protect children's rights in various countries.

Because of this, but mostly because of the UNCRC's hegemonic standing -it is the only global children's rights charter in existence, without any international grassroots children's movement pushing for another charter- it must be acknowledged as the legal currency in use regarding children's rights. However, a key caveat must be added to underline that as an instrument of children's rights, that is, of rights that should belong to children, the UNCRC is a tool "in the waiting"; waiting for children to come and make a space for their own meanings and definitions in a space originally not of their making. Organized working children in the majority world have already started to tread this path, using the discourse about their rights enshrined in the UNCRC to struggle for further rights, such as their right to work with dignity which is not included in the UNCRC.

\section{Referências / References}

Cordero Arce, M. (2015). Hacia un discurso emancipador de los derechos de las niñas y los niños. Lima: Ifejant. 